\title{
Studi hasil belajar kognitif pada materi udara bersih bagi pernapasan melalui model numbered heads together

\section{Agusta Kurniati*, Hendrikus Julung, Fitri Lestari}

STKIP Persada Khatulistiwa Sintang, J1. Sengkuang, Sintang (786I4), KAL-BAR, Indonesia

Korespondensi penulis: agusta.kurniati@gmail.com

Informasi artikel

Riwayat artikel:

Dikirim 03 Februari 2020

Direvisi 02 Maret 2020

Diterima 05 April 2020

Dipublikasi 07 April 2020

\section{Kata kunci:}

Numbered heads together, hasil belajar kognitif, pembelajaran tematik

\section{ABSTRAK}

Masih banyak siswa yang memperoleh hasil belajar kognitif dibawah nilai KKM. Studi ini bertujuan mengkaji studi hasil belajar kognitif pada materi udara bersih bagi pernapasan melalui model Numbered Heads Together (NHT). Pendekatan yang digunakan adalah kuantitatif dengan rancangan berupa nonequivalent control group design. Sampel adalah siswa kelas $\mathrm{V}$ SDN 23 Menyumbung yang berjumlah 35 siswa. Instrumen berupa soal tes pilihan ganda sebanyak 24 soal yang terkait indikator kognitif. Hasil uji hipotesis menunjukkan nilai probalilitas $(0,000)$ dan lebih kecil dari alpha $(0,05)$ sehingga dapat disimpulkan bahwa model NHT berpengaruh signifikan terhadap hasil belajar kognitif pada materi pentingnya udara bersih bagi pernapasan di SDN 23 Menyumbung tahun pelajaran $2019 / 2020$

\section{ABSTRACT}

\section{Keywords:}

Numbered heads together, cognitive learning outcomes, thematic learning
Study of cognitive learning outcomes in clean air material for breathing through the numbered heads together model. There are still many students who get cognitive learning outcomes below the KKM score. This study aims to examine cognitive learning outcomes in clean air material for breathing through the Numbered Heads Together (NHT) learning model. The approach is quantitative with a design in the form of nonequivalent control group design. The sample is students in class $V$ SDN 23 Menyumbung, totaling 35 students. The instrument using was a multiple choice test item by 24 questions related to cognitive indicators. Hypothesis test results obtained a significant value $(0,000)$ and greater than alpha (0.05) so it can be concluded that the NHT learning model has a significant effect on cognitive learning outcomes on the material importance of clean air for breathing in SDN 23 Menyumbung to the $2019 / 2020$ academic year.

(C) 2020 Kurniati et al This is an open access article under the CC-BY-SA license

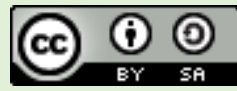

Sitasi: Kurniati, A., Julung, H., \& Lestari, F. (2020). Kajian hasil belajar kognitif pada materi udara bersih bagi pernapasan melalui model numbered heads together. JPBIO (Jurnal Pendidikan Biologi), 5(I), I06-II3. DOI: 10.31932/jpbio.v5i1.625

\section{PENDAHULUAN}

Pendidikan merupakan salah satu unsur yang sangat mendasar dalam kehidupan manusia yang turut menentukan kualitas sumber daya manusia (Reflianto et al., 2019). Oleh karena itu, pendidikan harus mampu mengali potensi peserta didik sesuai dengan perkembangannya. Berbagai kemampuan yang dimiliki oleh siswa tidak akan tumbuh jika pendidikan belum mampu memaksimalkan proses pembelajaran di kelas. Sidik (2016) mengungkapkan bahwa guru memiliki tanggungjawab atas terciptanya sumber daya manusia yang berkualitas. dol Kurniati et al Bjurnaljpbio@gmail.com 
Guru harus mampu menciptakan proses pembelajaran di sekolah dengan baik agar mampu menentukan kualitas peserta didik. Pendidik (guru) diharapkan memiliki inovasi dan kreasi dalam proses pembelajaran agar dapat berjalan sebagaimana mestinya dan akhirnya akan mempengaruhi hasil belajar siswa.

Hasil belajar merupakan indikator yang diukur dalam proses pembelajaran dengan tiga ranah yakni: kognitif, psikomotorik dan afektif. Hasil belajar kognitif merupakan kemampuan yang terkait dengan kegiatan mental otak. Supardi (2015) mengungkapkan bahwa kognitif merupakan kemampuan yang berhubungan dengan penguasaan, pertimbangan, informasi, pengolahan, pemecahan masalah, dan keyakinan. Terdapat enam jenjang dalam ranah kognitif mulai dari jenjang terendah sampai dengan jenjang yang paling tinggi yakni dari knowledge, comprehension, application, analysis, evaluation dan creation (Supardi, 2015). Hasil belajar kognitif merupakan pencapaian siswa dalam ranah pengetahuan yang turut serta menunjukkan keberhasilan suatu pembelajaran.

Namun, seringkali ditemukan berbagai permasalahan dalam proses pembelajaran yang menyebabkan rendahnya hasil belajar terutama pada ranah kognitif siswa. Hasil observasi tanggal 7 Maret 2019 di SDN 23 Menyumbung Sintang menunjukkan nilai ulangan harian siswa hanya I2\% di atas nilai KKM, sementara 88\% belum memenuhi KKM. Beberapa hasil penelitian terdahulu menunjukan bahwa hasil belajar kognitif siswa masih rendah (Mulyono et al., 2017; Queen et al., 2019). Hasil penelitian Munir (2018) menunjukkan bahwa hasil belajar kognitif siswa pada pelajaran matematika adalah 45,88\% yang berada dalam kategori rendah. Lebih lanjut, penelitian yang dilakukan oleh Efendi \& Sofnawandi (2016) bahwa hasil belajar kognitif siswa adalah 58,33\% dengan kategori rendah. Selanjutnya, penelitian Kristiningtyas (2017) menunjukkan bahwa hasil belajar kognitif siswa dalam membuat sketsa dan peta wilayah adalah 53,32\% dalam kategori rendah.

Rendahnya hasil belajar kognitif disebabkan oleh beberapa fasktor. Hasil wawancara dengan guru wali kelas memberikan informasi bahwa metode pembelajaran yang digunakan masih konvensional yaitu hanya melalui ceramah dan pemberian tugas. Fakta menunjukkan bahwa potensi yang dimiliki siswa di kelas V SDN 23 Menyumbung Sintang belum sepenuhnya tersalurkan. Hal ini mengakibatkan hasil belajar kognitif siswa masih rendah. Hasil belajar siswa yang rendah juga dipengaruhi oleh beberapa faktor yaitu, kurangnya minat belajar, kurangnya konsentrasi, rendahnya pemahaman siswa, serta kurangnya kedisiplinan siswa (Ardilla, 2017). Fakta ini didukung oleh pernyataan Harahap (2014) bahwa faktor penyebab rendahnya hasil belajar siswa adalah sikap belajar siswa yang pasif, guru kurang kreatif dalam menyampaian materi, pembelajaran monoton dan kurang inovatif dan masih menerapkan budaya menghapal dari pada memahami dalam proses pembelajaran.

Mengatasi masalah hasil belajar kognitif siswa yang belum maksimal maka dapat dilakukan dengan menerapkan model pembelajaran yang inovatif dan kreatif (Bustami et al, 20I8), salah satunya adalah model Number Heads Together (NHT). Model NHT adalah model pembelajaran yang menerapkan satu siswa mewakili kelompoknya dalam sistem sosial. Wijanarko (2017) menjelaskan model pembelajaran merupakan suatu pengalaman belajar untuk mencapai tujuan dan fungsi dalam merancang dan melaksanakan proses belajar mengajar. Dahni (2018) mengungkapkan bahwa model NHT merupakan pembelajaran yang memberikan kesempatan kepada siswa untuk saling berbagi ide dan saling mempertimbangkan jawaban yang paling tepat. Hal ini sejalan dengan pembelajaran tematik di mana pembelajaran tematik yang memberikan sebuah pemahaman dari beberapa materi dalam menghasilkan sebuah konsep baru pada peserta didik (Murfiah, 20I7).

Keunggulan dari model pembelajaran NHT adalah melibatkan siswa secara langsung dalam sintaks atau tahapan pembelajaran. Sintaks pembelajaran meliputi: I) penomoran (numbering), dimana guru membagi siswa dalam kelompok kecil serta memberikan nomor yang berbeda pada setiap siswa; 2) pengajuan pertanyaan (questioning), guru mengajukan pertanyaan kepada siswa dari materi yang dibelajarkan; 3) berpikir bersama (heads together), guru memberikan kesempatan kepada siswa untuk berdiskusi dalam kelompok guna menjawab pertanyaan yang telah diberikan; 4) pemberian jawaban (answering); guru menyebutkan nomor secara acak dan meminta siswa menyebutkan jawaban dari pertanyaan. Keunggulan dari model NHT adalah siswa pintar dapat mengajari siswa yang kurang pintar sehingga terjadinya interaksi antara siswa dalam proses pembelajaran, dan tidak ada yang mendominasi dalam kelompok karena memiliki nomor yang membatasinya (Shoimin, 20I4). Keunggulan NHT dapat membantu siswa dalam memahami materi yang disampaikan dan membantu guru dalam menciptakan suatu suasana belajar yang lebih aktif dan kreatif. Oleh karena itu, penelitian ini bertujuan untuk mengkaji hasil belajar kognitif pada materi udara bersih bagi pernapasan melalui model pembelajaran NHT.

\section{METODE PENELITIAN}

\section{Rancangan Penelitian}

Studi ini menggunakan pendekatan kuantitatif dengan metode quasi eksperimen. Rancangan eksperimental yang digunakan adalah nonequivalent control group design yang dapat dilihat pada Tabel I. 
Tabel I. Rancangan penelitian

\begin{tabular}{|c|c|c|c|c|}
\hline \multicolumn{2}{|c|}{ Kelompk } & Tes awal & Perlakuan & Tes akhir \\
\hline \multicolumn{2}{|c|}{ NHT } & $\mathrm{T}_{1}$ & $\mathrm{~N}$ & $\mathrm{~T}_{2}$ \\
\hline \multicolumn{2}{|c|}{ Konvensional } & $\mathrm{T}_{3}$ & $\mathrm{~K}$ & $\mathrm{~T}_{4}$ \\
\hline \multicolumn{5}{|c|}{ Keterangan: } \\
\hline $\mathrm{T}_{\mathrm{I}}$ & $:$ & \multicolumn{3}{|c|}{ Tes awal (pretest) kelas NHT } \\
\hline$T_{2}$ & : & \multicolumn{3}{|c|}{ Tes akhir (postest) kelas NHT } \\
\hline$T_{3}$ & : & \multicolumn{3}{|c|}{ Tes awal (pretest) kelas konvensional } \\
\hline $\mathrm{T}_{4}$ & $:$ & \multicolumn{3}{|c|}{ Tes akhir (postest) kelas konvensional } \\
\hline $\mathrm{N}$ & : & \multicolumn{3}{|c|}{ Perlakuan yang diberikan model pembelajaran NHT } \\
\hline K & & \multicolumn{3}{|c|}{ Pembelajaran denghan metode konvensional } \\
\hline
\end{tabular}

\section{Populasi dan Sampel Penelitian}

Populasi adalah siswa kelas V SDN 23 Menyumbung Sintang yakni kelas VA dan VB. Sampel yaitu siswa kelas VB berjumlah 18 siswa sebagai kelas NHT dan siswa kelas VA berjumlah I7 siswa sebagai kelas konvensional. Pengambilan sampel menggunakan purposive sampling, yaitu berdasarkan pertimbangan nilai rerata siswa yang tidak jauh berbeda yakni kelas VB sebagai kelas NHT sebesar 55 dan kelas VA sebagai kelas konvensional sebesar 65 .

\section{Instrumen Penelitian}

Instrumen berupa soal tes berbentuk tes objektif (pilihan ganda) sebanyak 24 soal. Rubrik penilaian hasil belajar kognitif siswa mengacu pada indikator hasil belajar kognitif taksonomi bloom (Majid, 2017). Instrumen tes sebelum digunakan diujicoba untuk mengetahui nilai reliabilitas dan validitas butir soal. Analisis ujicoba soal tes menggunakan Anates V4. Hasil uji reliabilitas sebesar 0,78 maka soal tes tersebut masuk dalam kategori reliabilitas tinggi dan hasil uji validitas dari 30 soal yang diujicoba terdapat I4 soal sangat singnifikan, IO soal signifikan, dan 6 soal tidak signifikan yang dapat dilihat pada Tabel 2.

Tabel 2. Rangkuman hasil validasi soal test menggunakan anates $v 4$ program

\begin{tabular}{lllc}
\hline No. & Signifikansi & Nomor soal & Jumlah \\
\hline $\mathrm{I}$ & Sangat signifikan & $\mathrm{I}, 2,3,4,5,7,8,9, \mathrm{I} 0, \mathrm{I} 5, \mathrm{I} 9,24,25,29$ & $\mathrm{I} 4$ \\
\hline 2 & Signifikan & $6, \mathrm{I} 8,20,2 \mathrm{I}, 22,23,26,27,28,30$ & $\mathrm{I} 0$ \\
\hline 3 & Tidak signifikan & $\mathrm{II}, \mathrm{I} 2, \mathrm{I} 3, \mathrm{I} 4, \mathrm{I} 6, \mathrm{I} 7$ & 6 \\
\hline
\end{tabular}

\section{Prosedur Penelitian}

Penelitian ini terdiri dari kelompok treatment dengan NHT dan kelompok control dengan pembelajaran konvensional. Kedua kelompok tersebut diberikan pretest (tes awal) untuk mengetahui keadaan awal siswa terkait hasil belajar kognitif. Selanjutnya, dilakukan proses pembelajaran untuk kelompok treatment diberi perlakuan dengan pembelajaran menggunakan model NHT sedangkan untuk kelompok control dilakukan pembelajaran konvensional. Terakhir, setiap kelompok baik kelompok treatment maupun control diberi posttest (tes akhir) untuk mengetahui nilai akhir siswa. Setelah semua data terkumpul maka kemudian data dianalisis dan ditarik kesimpulan dari semua data.

\section{Teknik Analisis Data}

Analisis data menggunakana analisis deskriptif untuk mengetahui rerata hasil belajar kognitif dan analisis inferensial. Sebelumnya, dilakukan uji prasyarat yakni uji normalitas dan homogenitas. Uji hipotesis dilakukan dengan teknik independent samples test. Analisis data menggunakan SPSS Versi I8.

Tabel 3. Nilai rerata hasil belajar kognitif siswa

\begin{tabular}{rcccc}
\hline \multirow{2}{*}{ Nilai } & \multicolumn{2}{c}{ Kelas NHT } & \multicolumn{2}{c}{ Kelas konvensional } \\
& Tes awal & Tes akhir & Tes awal & Tes akhir \\
\hline Tertinggi & 60 & 95 & 65 & 80 \\
\hline Terendah & I0 & 60 & 25 & 50 \\
\hline Rata-rata & 36,94 & 78,05 & 45,29 & 60,88 \\
\hline
\end{tabular}


HASIL PENELITIAN

Hasil penelitian didapatkan dari kegiatan tes awal dan tes akhir yang selanjutnya dilakukan analisis deskriptif. Hasil analisis deskriptif pada Tabel 3. mendeskripsikan bahwa nilai rerata hasil belajar kognitif siswa pada kegiatan tes awal baik kelas NHT maupun konvensional tidak berbeda. Selanjutnya, nilai rerata tes akhir kelas NHT lebih tinggi dibandingkan kelas konvensional.

Tabel 4. Rangkuman analisis indikator hasil belajar kognitif pretest kelas NHT

\begin{tabular}{llllllll}
\hline No & Kode siswa & CI & C2 & C3 & C4 & Jumlah & Persentase (\%) \\
\hline I & AI & 3 & I & I & 2 & 7 & $35,00 \%$ \\
\hline 2 & A2 & 3 & 2 & 0 & 2 & 7 & $35,00 \%$ \\
\hline 3 & A3 & 4 & I & I & 2 & 8 & $40,00 \%$ \\
\hline 4 & A4 & I & 3 & 2 & I & 7 & $35,00 \%$ \\
\hline 5 & A5 & 4 & 2 & I & I & 8 & $40,00 \%$ \\
\hline 6 & A6 & I & I & I & I & 4 & $20,00 \%$ \\
\hline 7 & A7 & I & I & 0 & 0 & 2 & $10,00 \%$ \\
\hline 8 & A8 & 2 & 3 & 2 & I & 8 & $40,00 \%$ \\
\hline 9 & A9 & 2 & 3 & 2 & 3 & I0 & $50,00 \%$ \\
\hline I0 & AI0 & 2 & 0 & I & I & 4 & $20,00 \%$ \\
\hline II & AII & I & 5 & 2 & 2 & I0 & $50,00 \%$ \\
\hline I2 & AI2 & 4 & I & I & 2 & 8 & $40,00 \%$ \\
\hline I3 & AI3 & 3 & 2 & 2 & 2 & 9 & $45,00 \%$ \\
\hline I4 & AI4 & 2 & I & I & 0 & 4 & $20,00 \%$ \\
\hline I5 & AI5 & 4 & 5 & 2 & I & I2 & $60,00 \%$ \\
\hline I6 & AI6 & 4 & 4 & 3 & I & I2 & $60,00 \%$ \\
\hline I7 & AI7 & 2 & 2 & I & 2 & 7 & $35,00 \%$ \\
\hline I8 & AI8 & 2 & 2 & I & I & 6 & $30,00 \%$ \\
\hline Jumlah & 45 & 39 & 24 & 25 & I33 & $36,94 \%$ \\
\hline Rata-rata & 2,50 & $2, I 7$ & I,33 & I,39 & 7,39 & $36,94 \%$ \\
\hline Persentase indikator & $4 I, 67 \%$ & $36, I 1 \%$ & $26,67 \%$ & $46,30 \%$ & $36,94 \%$ & $36,94 \%$ \\
\hline
\end{tabular}

Tabel 5. Rangkuman analisis indikator hasil belajar kognitif posttest kelas NHT

\begin{tabular}{|c|c|c|c|c|c|c|c|}
\hline No & Kode siswa & $\mathrm{CI}$ & $\mathrm{C} 2$ & $\mathrm{C} 3$ & $\mathrm{C} 4$ & Jumlah & Persentase (\%) \\
\hline $\mathrm{I}$ & AI & 6 & 6 & 4 & I & 17 & $85,00 \%$ \\
\hline 2 & A2 & 3 & 6 & 3 & 3 & I5 & $75,00 \%$ \\
\hline 3 & A3 & 5 & 5 & 5 & 2 & I7 & $85,00 \%$ \\
\hline 4 & A4 & 6 & 5 & 3 & 2 & I6 & $80,00 \%$ \\
\hline 5 & A5 & 6 & 4 & 4 & 2 & 16 & $80,00 \%$ \\
\hline 6 & A6 & 3 & 3 & 4 & 2 & I2 & $60,00 \%$ \\
\hline 7 & A7 & 4 & 5 & I & 2 & $\mathrm{I} 2$ & $60,00 \%$ \\
\hline 8 & A8 & 4 & 6 & 4 & 2 & 16 & $80,00 \%$ \\
\hline 9 & A9 & 5 & 4 & 5 & 3 & I7 & $85,00 \%$ \\
\hline 10 & AIO & 4 & 4 & 2 & 2 & I2 & $60,00 \%$ \\
\hline II & AII & 5 & 6 & 5 & 2 & I8 & $90,00 \%$ \\
\hline I2 & AI2 & 6 & 5 & 4 & 2 & 17 & $85,00 \%$ \\
\hline 13 & AI3 & 5 & 4 & 5 & 2 & 16 & $80,00 \%$ \\
\hline I4 & AI4 & 5 & 5 & 3 & 0 & I3 & $65,00 \%$ \\
\hline I5 & AI5 & 5 & 6 & 5 & 3 & 19 & $95,00 \%$ \\
\hline I6 & AI6 & 6 & 6 & 4 & 3 & 19 & $95,00 \%$ \\
\hline 17 & AI7 & 4 & 6 & 3 & 2 & $\mathrm{I} 5$ & $75,00 \%$ \\
\hline 18 & AI8 & 3 & 4 & 4 & 3 & I4 & $70,00 \%$ \\
\hline \multicolumn{2}{|c|}{ Jumlah } & 85 & 90 & 68 & 38 & $28 \mathrm{I}$ & $78,06 \%$ \\
\hline \multicolumn{2}{|c|}{ Rata-rata } & 4,7 & 5,0 & 3,6 & $2, \mathrm{I}$ & $\mathrm{I} 5,6 \mathrm{I}$ & $78,06 \%$ \\
\hline \multicolumn{2}{|c|}{ Persentase Indikator } & $78,70 \%$ & $83,33 \%$ & $75,56 \%$ & $70,37 \%$ & $78,05 \%$ & $78,06 \%$ \\
\hline
\end{tabular}


Hasil belajar ranah kognitif siswa kelas NHT dan konvensional diperoleh dari tes awal (pretest) dan tes akhir (posttest). Pretest dilaksanakan sebelum adanya perlakuan yang diberikan dan posttest dilaksanakan setelah adanya perlakuan yang diberikan. Indikator hasil belajar kognitif yang diukur pada penelitian ini meliputi aspek mengingat (CI), memahami (C2), menerapkan (C3), dan menganalisis (C4) Hasil analisis dari indikator hasil belajar kognitif pretest pada kelas NHT dapat dilihat Tabel 4.

Tabel 6. Rangkuman analisis indikator hasil belajar kognitif pretest konvensional

\begin{tabular}{llllllll}
\hline No & Kode siswa & CI & C2 & C3 & C4 & Jumlah & Persentase (\%) \\
\hline I & BI & 2 & 2 & 4 & 3 & I & $55,00 \%$ \\
\hline 2 & B2 & 2 & 2 & 2 & 3 & 9 & $45,00 \%$ \\
\hline 3 & B3 & 4 & 3 & 3 & 3 & I3 & $65,00 \%$ \\
\hline 4 & B4 & 3 & 2 & I & 2 & 8 & $40,00 \%$ \\
\hline 5 & B5 & 3 & I & 0 & I & 5 & $25,00 \%$ \\
\hline 6 & B6 & 3 & I & 3 & 3 & I0 & $50,00 \%$ \\
\hline 7 & B7 & 3 & I & 3 & I & 8 & $40,00 \%$ \\
\hline 8 & B8 & 4 & I & I & I & 7 & $35,00 \%$ \\
\hline 9 & B9 & 3 & 3 & 4 & I & II & $55,00 \%$ \\
\hline I0 & BI0 & 3 & I & I & 2 & 7 & $35,00 \%$ \\
\hline II & BII & 4 & 3 & 0 & 2 & 9 & $45,00 \%$ \\
\hline I2 & BI2 & I & 2 & 4 & I & 8 & $40,00 \%$ \\
\hline I3 & BI3 & 3 & 4 & 4 & I & I2 & $60,00 \%$ \\
\hline I4 & BI4 & 2 & 2 & I & 2 & 7 & $35,00 \%$ \\
\hline I5 & BI5 & I & 2 & 3 & 0 & 6 & $30,00 \%$ \\
\hline I6 & BI6 & 2 & 4 & 5 & 2 & I3 & $65,00 \%$ \\
\hline I7 & BI7 & 4 & 2 & 2 & 2 & I0 & $50,00 \%$ \\
\hline Jumlah & 47 & 36 & $4 \mathrm{I}$ & 30 & I54 & $45,29 \%$ \\
\hline Rata-rata & 2,8 & $2, \mathrm{I}$ & 2,4 & I,8 & 9,06 & $45,29 \%$ \\
\hline Persentase Indikator & $46,07 \%$ & $35,29 \%$ & $48,23 \%$ & $58,82 \%$ & $45,29 \%$ & $45,29 \%$ \\
\hline
\end{tabular}

Tabel 7. Rangkuman analisis indikator hasil belajar kognitif posttest konvensional

\begin{tabular}{|c|c|c|c|c|c|c|c|}
\hline No & Kode siswa & $\mathrm{CI}$ & $\mathrm{C} 2$ & $\mathrm{C} 3$ & $\mathrm{C} 4$ & Jumlah & Persentase (\%) \\
\hline $\mathrm{I}$ & BI & 4 & 3 & 4 & 2 & I3 & $65,00 \%$ \\
\hline 2 & B2 & 3 & 4 & 2 & 2 & II & $55,00 \%$ \\
\hline 3 & B3 & 5 & 5 & 3 & 2 & I5 & $75,00 \%$ \\
\hline 4 & B4 & 4 & 0 & 5 & 3 & $\mathrm{I} 2$ & $60,00 \%$ \\
\hline 5 & B5 & 2 & 3 & 3 & 2 & 10 & $50,00 \%$ \\
\hline 6 & B6 & 3 & 3 & 5 & 3 & $\mathrm{I} 4$ & $70,00 \%$ \\
\hline 7 & B7 & 5 & 2 & 5 & 0 & $\mathrm{I} 2$ & $60,00 \%$ \\
\hline 8 & B8 & 4 & 4 & 2 & 0 & 10 & $50,00 \%$ \\
\hline 9 & B9 & 4 & 5 & 2 & 2 & $\mathrm{I3}$ & $65,00 \%$ \\
\hline I0 & BIO & 3 & 4 & 2 & I & 10 & $50,00 \%$ \\
\hline II & BII & 3 & 5 & I & 3 & $\mathrm{I} 2$ & $60,00 \%$ \\
\hline 12 & $\mathrm{BI} 2$ & 2 & 4 & 4 & 2 & $\mathrm{I} 2$ & $60,00 \%$ \\
\hline 13 & $\mathrm{BI} 3$ & 5 & 4 & 4 & I & I4 & $70,00 \%$ \\
\hline I4 & BI4 & 2 & 4 & 2 & 2 & I0 & $50,00 \%$ \\
\hline 15 & BI5 & 2 & 3 & 4 & $\mathrm{I}$ & I0 & $50,00 \%$ \\
\hline I6 & BI6 & 3 & 5 & 5 & 3 & I6 & $80,00 \%$ \\
\hline 17 & BI7 & 4 & 3 & 4 & 2 & 13 & $65,00 \%$ \\
\hline \multicolumn{2}{|c|}{ Jumlah } & 58 & $6 \mathrm{I}$ & 57 & $3 I$ & 207 & $60,88 \%$ \\
\hline \multicolumn{2}{|c|}{ Rata-rata } & 3,4 & 3,6 & 3,4 & 1,9 & 12,18 & $60,88 \%$ \\
\hline \multicolumn{2}{|c|}{ Persentase Indikator } & $56,86 \%$ & $59,80 \%$ & $60,00 \%$ & $60,78 \%$ & $60,88 \%$ & $60,88 \%$ \\
\hline
\end{tabular}


Hasil belajar kognitif siswa pada pretest kelas NHT dengan perolehan nilai rerata pada indikator CI sebesar 4I,67\%, C2 sebesar 36,II\%, C3 sebesar 26,67\%, dan C4 sebesar 46,30\%, dengan kategori "rendah". Hasil analisis indikator hasil belajar kognitif posttest pada kelas NHT dapat dilihat Tabel 5. Hasil belajar kognitif siswa pada posttest dengan perolehan nilai rerata pada indikator CI sebesar 78,70\%, C2 sebesar 83,33\%, C3 sebesar 75,56\%, dan C4 sebesar 70,37\%, dengan kategori "tinggi”. Selanjutnya, hasil analisis indikator hasil belajar kognitif pretest pada kelas konvensional dapat dilihat Tabel 6 .

Hasil belajar kognitif siswa pada pretest kelas konvensional dengan perolehan nilai rerata pada indikator CI sebesar 46,07\%, C2 sebesar 35,29\%, C3 sebesar 48,23\%, dan C4 sebesar 58,82\%, dengan kategori "rendah". Hasil analisis indikator hasil belajar kognitif posttest di kelas konvensional dapat dilihat pada Tabel 7. Hasil belajar kognitif siswa pada posttest kelas konvensional dengan perolehan nilai rerata pada indikator CI sebesar 56,86\%, C2 sebesar 59,80\%, C3 sebesar 60,00\%, dan C4 sebesar 60,78\%, dengan kategori "sedang". Analisis tes hasil belajar kognitif menggunakan SPSS Versi I8. Meliputi uji normalitas, uji homogenitas dan uji hipotesis. Uji normalitas data dapat dilihat pada Tabel 8.

Tabel 8. Rangkuman uji normalitas data kelas NHT dan kelas konvensional

\begin{tabular}{lllcccl}
\hline Kelas & Jenis tes & $x^{-}$ & S & Sig. & a & Kesimpulan \\
\hline NHT & Tes awal & 36,94 & I3,62 & 0,200 & 0,05 & Normal \\
\hline & Tes akhir & 78,05 & II,26 & 0,129 & 0.05 & Normal \\
\hline Konvensional & Tes awal & 45,29 & II,92 & 0,200 & 0,05 & Normal \\
\hline & Tes akhir & 60,88 & 9,39 & 0,200 & 0,05 & Normal \\
\hline
\end{tabular}

Hasil uji normalitas data pada Tabel 8. menunjukkan kelas NHT dan konvensional baik pada tes awal dan tes akhir data berdistribusi normal. Hasil uji homogenitas pada Tabel 9. juga menunjukan kelas NHT dan konvensional baik pada tes awal dan tes akhir data berdistribusi homogen.

Tabel 9. Hasil uji homogenitas kelas NHT dan kelas konvensional

\begin{tabular}{lcccc}
\hline Jenis tes & Alpha $(\mathbf{a})$ & Nilai signifikan & \multicolumn{1}{c}{ Keterangan } & Kesimpulan \\
\hline Tes awal & 0,05 & $0,84 \mathrm{I}$ & $0,84 \mathrm{I}>0,05$ & Homogen \\
\hline Tes akhir & 0,05 & 0,445 & $0,445>0,05$ & Homogen \\
\hline
\end{tabular}

Hasil uji hipotesis tes awal menunjukkan nilai probabilitas (sig.) sebesar 0,063 dan lebih besar dari nilai alpha 0,05 sehingga tidak ada perbedaan yang signifikan hasil belajar kognitif dari kedua kelompok. Selanjutnya, hasil tes akhir menunjukkan nilai signifikan sebesar 0,000 dan lebih kecil dari nilai alpha 0,05. Hal ini dapat diartikan bahwa terdapat pengaruh yang signifikan model pembelajaran NHT terhadap hasil belajar kognitif siswa pada materi udara bersih bagi pernapasan di kelas V Sekolah Dasar Negeri 23 Menyumbung (Tabel I0).

Tabel I0. Uji hipotesis

\begin{tabular}{lccc}
\hline Jenis tes & Sig. (2-tailed) & Alpha $(\mathbf{a})$ & Kesimpulan \\
\hline Tes awal & 0,063 & 0,05 & $H_{0}$ diterima \\
\hline Tes akhir & 0,000 & 0,05 & $H_{1}$ diterima \\
\hline
\end{tabular}

\section{PEMBAHASAN}

Hasil uji t-test pada tes awal menunjukkan bahwa tidak terdapat perbedaan hasil belajar kognitif yang signifikan sebelum dilakukan proses pembelajaran. Hal tersebut menunjukkan bahwa kedua kelas memiliki kemampuan awal yang sama. Hasil analisis inferensial pada tes akhir menunjukkan bahwa terdapat pengaruh yang signifikan penerapan model NHT terhadap hasil belajar kognitif. Adanya pengaruh menunjukkan bahwa terdapat perbedaan dari setiap perlakuan yang diberikan dalam mempengaruhi hasil belajar kognitif siswa. Hasil analisis deskriptif menunjukkan bahwa nilai rerata kelas NHT lebih tinggi dibandingkan kelas konvensional. Hasil penelitian ini sejalan dengan penelitian Melindawati et al. (2018) bahwa model pembelajaran NHT berpengaruh signifikan terhadap hasil belajar siswa. Hal ini disebabkan karena pembelajaran NHT memiliki keunggulan dibandingkan pembelajaran konvensional.

Keunggulan dari tahapan model pembelajaran NHT adalah pada tahap berpikir bersama, dimana siswa diberikan kesempatan kepada siswa untuk berkerjasama dengan rekan sesamanya, bersama memahami materi pelajaran yang diberikan, bersikap aktif ketika menerima pertanyaan dari guru dan merespon jawaban dari teman. 
Pendapat ini sesuai dengan Sulasmi (2016) yang menyatakan model NHT dapat memungkinkan siswa untuk lebih aktif dalam belajar dan akan menciptakan tanggungjawab penuh dalam memahami materi dipelajari baik secara individu maupun berkelompok. Zativalen et al. (2017) menjelaskan bahwa NHT memberikan siswa lebih banyak waktu berpikir, saling menjawab satu sama lain, menjawab dan melibatkan siswa dalam menelaah materi yang dipelajari. Dengan demikian, model pembelajaran NHT sangat membantu siswa dalam memahami materi yang dipelajari dan dapat meningkatkan hasil belajar kognitif siswa.

Hasil belajar kognitif siswa pada kelas NHT mengalami peningkatan karena model NHT memiliki kelebihan pada sintaknya yaitu diskusi masalah dimana dalam diskusi masalah siswa saling bertukar pendapat serta informasi yang diperoleh dan saling berbagi ilmu untuk menyelesaikan permasalahan yang terdapat pada LKPD, sehingga lebih banyak waktu siswa untuk memahami materi pelajaran dengan baik. Pendapat ini sesuai dengan Al-Tabani (20I4) kelebihan NHT adalah jenis pembelajaran kooperatif untuk melibatkan lebih banyak siswa dalam menelaah materi yang tercakup dalam suatu pembelajaran dan mengecek pemahaman mereka terhadap isi pembelajaran tersebut. Hasil penelitian ini sejalan dengan penelitian terdahulu yang dilakukan oleh Putranti \& Widiastuti (2016) hasil belajar kognitif siswa mengalami peningkatan dengan penerapan model pembelajaran NHT didapat hasil belajar kognitif pada pertemuan pertama sebesar 39,71\% dan pertemuan kedua sebesar 84\%. Kistian (2018) mengungkapkan bahwa dengan menerapkan model pembelajaran NHT dapat meningkatkan prestasi hasil belajar siswa.

Hamdayana (2015) menjelaskan langkah-langkah model pembelajaran NHT adalah persiapan, pembentukan kelompok, tiap kelompok harus memiliki buku paket, diskusi masalah, memanggil nomor anggota, dan memberikan kesimpulan. Siswa yang awalnya malu dan pendiam diharuskan untuk aktif pada sintak NHT, karena jika siswa tidak aktif berdiskusi maka tidak banyak ilmu yang didapatkan. Tutor sebaya merupakan salah satu kelebihan NHT yang berperan penting dalam diskusi masalah ini yang membuat siswa dalam kelompok saling berbagi informasi yang mereka ketahui, siswa yang pandai mengajari siswa yang kurang pandai sehingga pada kelompok belajar semuanya aktif untuk mencari pengetahuan dari masing-masing anggota kelompoknya.

Model pembelajaran NHT dapat mengurangi waktu siswa untuk bermain-main dan mengandalkan teman dalam kelompok sehingga tidak hanya satu individu saja yang memahami materi pembelajaran dan yang dapat menyelesaikan permasalahkan pada LKPD melainkan semua siswa dalam kelompok, sehingga pada tes hasil belajar kognitif siswa dapat mengerjakan soal tes dengan baik dan hasil belajar kognitif siswa mengalami peningkatan $\mathrm{Hal}$ ini sejalan dengan penelitian yang pernah dilakukan Djudin et al. (2018) bahwa terdapat perbedaan yang signifikan antara rata-rata hasil belajar siswa yang menggunakan model pembelajaran NHT dengan siswa yang menggunakan metode ceramah bervariasi.

\section{SIMPULAN}

Melihat hasil analisis data yang diperoleh maka dapat disimpulkan bahwa terdapat pengaruh yang signifikan model pembelajaran NHT terhadap hasil belajar kognitif siswa kelas $\mathrm{V}$ pada materi pentingnya udara bersih bagi pernapasan di SDN 23 Menyumbung Sintang. Dengan demikian, model pembelajaran NHT disarankan dapat diaplikasikan dalam pembelajaran, karena memiliki potensi untuk memudahkan siswa memahami materi pembelajaran, sehingga dapat memperbaiki hasil belajar kognitif siswa.

\section{REFERENSI}

Al-Tabani, B.I.T. (20I4). Mendesain model pembelajaran inovatif, progtesif, dan kontekstual. Jakarta: Prenadamedia Group.

Ardilla, A., \& Hartanto, S. (2017). Faktor yang mempengaruhi rendahnya hasil belajar matematika siswa mts iskandar muda batam. PYTHAGORAS, 6(2), I75-I86. DOI: 10.33373/pythagoras.v6i2.966

Bustami, Y., Syafruddin, D., \& Afriani, R. (2018). The implementation of contextual learning to enhance biology students' critical thinking skills. Jurnal Pendidikan IPA Indonesia, 7(4), 45I-457. DOI: I0.I5294/jpii.v7i4.II72I

Dahni, A. (2018). Penerapan model kooperatif tipe nht untuk meningkatkan hasil belajar pkn siswa kelas vi sd negeri 010 keresek kecamatan gunung toar. Jurnal PAJAR (Pendidikan dan Pengajaran), 2(2), 234-239. DOI: $10.33578 /$ pjr.v2i2.5072

Djudin, R., Trisianawati, E., \& Stianingsih, Y.K. (2018). Pengaruh penerapan model pembelajaran numbered head together (nht) terhadap hasil belajar siswa. Jurnal Berkala Ilmiah Pendidikan Fisika, 6(3), 354-36I. DOI: I0.20527/bipf.v6i3.5295 
Efendi, I., \& Sofnawandi. (2016). Peningkatan keterampilan sosial dan hasil belajar kognitif siswa melalui metode belajar aktif tipe gge (group to group exchange). Jurnal Pendidikan Mandala, I(I), 42-49. http://ejournal.mandalanursa.org/index.php/JUPE/article/view/54

Hamdayana, J. (2015). Model dan metode pembelajaran kreatif dan berkarakter. Bogor: Ghalia Indonesia.

Harahap, N. (20I4). Hubungan antara motivasi dan aktivitas belajar siswa terhadap hasil belajar kognitif siswa dengan penerapan model pembelajaran kooperatif tipe student teams achievement division pada konsep ekosistem. Jurnal Pendidikan, 5(I), 35-46. https:/ visipena.stkipgetsempena.ac.id/?journal=home\&page $=$ article\&op $=$ view\&path\%5B\%5D $=69$ ?jou rnal $=$ home\&page $=$ article\&op $=$ view\&path $\% 5 \mathrm{~B} \% 5 \mathrm{D}=69$

Kistian, A. (2018). Pengaruh model pembelajaran numbered head together (nht) terhadap hasil belajar matematika siswa di kelas iv sdn 4 banda aceh. Genta Mulia: Jurnal Ilmiah Pendidikan, 922), 7I-82. https://ejournal.stkipbbm.ac.id/index.php/gm/article/view/I69

Kristiningtyas, W. (2017). Peningkatan hasil belajar siswa aspek kognitif dan psikomotorik dalam membuat sketsa dan peta wilayah yang menggambarkan objek geografi melalui metode survei lapangan. Refleksi Edukatika: Jurnal Ilmiah Kependidikan, 8(I), 28-34. DOI: 10.24176/re.v8iI.I782

Majid, A. (2017). Penilaian autentik proses dan hasil belajar. Bandung: Remaja Rosdakarya.

Melindawati, S., Irradatillah, \& Marcelina, S. (2018). Pengaruh penerapan model kooperatif tipe numbered head together (nht) terhadap hasil belajar ips siswa di kelas v sdn OI bandar buat padang. Jurnal Inovasi Pendidikan dan Pembelajaran Sekolah Dasar, 2(2), 64-77. DOI: 10.24036/jippsd.v2i2.I02706

Mulyono, O., Bustami, Y., \& Julung, H. (2017). Peningkatan hasil belajar kognitif siswa biologi sekolah menengah pertama melalui metode demonstrasi. JPBIO (Jurnal Pendidikan Biologi), 2(2), I5-I9. DOI: I0.31932/jpbio.v2i2.220

Munir, P.N. (2018). Pengaruh inteligensi intrapersonal terhadap hasil belajar kognitif matematika melalui motivasi belajar siswa. Jurnal Penelitian Matematika dan Pendidikan Matematika, I(I), 45-50. https://journal.uncp.ac.id/index.php/proximal/article/view/846

Murfiah, U. (2017). Pembelajaran terpadu teori dan praktik terbaik di sekolah. Bandung: Refika Aditama.

Putranti, P.A., \& Widiastuti. (2016). Penerapan metode numbered heads together (nht) untuk meningkatkan hasil belajar kognitif ipa di sd kristen gunungsitoli utara. A Journal of Language, Literature, Culture, and Education POL YGLOT, I2(2), I28-I40. DOI: I0.19166/pji.vI2i2.370

Queen, Y.A., Supiandi, M.I., \& Ege, B. (2019). Pengaruh model think pair and share berbasis media tree chart terhadap hasil belajar kognitif pada materi keanekaragaman hayati. JPBIO (Jurnal Pendidikan Biologi), 4(I), OI-08. DOI: I0.31932/jpbio.v4iI.355

Reflianto, A., Bustami, Y., \& Syafruddin, D. (2019). Efektivitas metode sosiodrama terhadap hasil belajar kognitif dan minat belajar siswa biologi. Assimilation: Indonesian Journal of Biology Education (AIJBE), 2(I), I-6. DOI: I0.17509/aijbe.v2iI.I4I72

Shoimin, A. (2014). Model Pembelajaran inovatif dalam kurikulum 2013. Yogyakarta: Ar-ruzz Media.

Sidik, F. (2016). Guru berkualitas untuk sumber daya manusia berkualitas. Tadbir: Jurnal Manajemen Pendidikan Islam, 4(2), I09-II4. http://journal.iaingorontalo.ac.id/index.php/tjmpi/article/view/444

Sulasmi. (2016). Meningkatkatkan prestasi belajar matematika melalui model pembelajaran kooperatif tipe numbered head together (nht) di kelas vii smpn 4 mataram semester genap tahun pelajaran 2009/2010. Jurnal Ilmiah Mandala Education, 2(2), I-8. DOI: I0.363I2/jime.v2i2.I6

Supardi. (2015). Penilaian autentik pembelajatan afektif, kognitif, dan psikomotor. Jakarta: Raja Grafindo Persada.

Wijanarko, Y. (2017). Model pembelajaran make a match untuk pembelajaran ipa yang menyenangkan. Jurnal Taman Cendekia, I(I), 52-59. DOI: I0.30738/tc.vIiI.I579

Zativalen, O., Hasanah, M., \& Silthon. (20I7). Pengaruh metode number head together (nht) terhadap hasil belajar pengetahuan pada pembelajaran tematik kelas v sdn dinoyo 2 kota malang. Jurnal Pendidikan, I(5), 855-860. DOI: http://dx.doi.org/I0.I7977/jp.vIi5.6276 